\title{
ANALISIS DETERMINAN PADA SISTEM GRAMATIKAL FRASA NOMINA BAHASA PRANCIS DALAM BUKU AJAR "ECHO"
}

\author{
Roswita Lumban Tobing \\ Fakultas Bahasa dan Seni, Universitas Negeri Yogyakarta \\ roswitalt@uny.ac.id
}

\begin{abstract}
ABSTRAK
Artikel ini merupakan hasil penelitian tentang bentuk-bentuk pendamping nomina bahasa Prancis yang berfungsi sebagai determinan pada frasa nomina dan konstruksi pembentukannya. Tujuan penelitian ini adalah mengkaji dan menjelaskan unsur-unsur/ bentuk-bentuk yang digunakan sebagai determinan pada frasa nomina bahasa Prancis dan menjelaskan konstruksi determinan yang digunakan dalam frasa nomina bahasa Prancis tersebut. Teknik yang digunakan dalam pengumpulan data tentang determinan dalam bahasa Prancis dilakukan dengan teknik baca dan teknik catat. Untuk setiap data yang ditemukan dicatat dan diklasifikasi untuk dimasukkan ke tabel data. Data yang telah dikumpulkan selanjutnya dianalisis. Analisis data menggunakan pendekatan struktural untuk melihat sistem gramatikal frasa nomina bahasa Prancis. Analisis tersebut dipadukan dengan acuan semantik untuk melihat keberterimaan sebuah konstruksi. Hasil penelitian menujukkan bahwa unsur pembentuk frasa nomin (nomina dan determinan) bersifat obligatoris. Jenis determinan pada frasa nomina Bahasa Prancis adalah (1) l'article (indéfini/défini), (2) l'adjectif (démonstratif, posessif, numeral, indéfini dan qualificatif). Makna yang terkandung pada setiap frasa nomina Bahasa Prancis tergantung pada hasil konstruksi.
\end{abstract}

Kata Kunci: bahasa Prancis, frasa nomina, determinan, konstruksi

\section{DETERMINANT ANALYSIS ON GRAMATICAL SYSTEM OF FRENCH NOUN PHRASES IN "ECHO"}

\begin{abstract}
This article is the result of research on forms of French noun companion that serves as a determinant on the noun phrases and its construction of formation. The objective of this study is to examine and to explain the elements used as determinants of the French noun phrases and to explain the construction of the determinants used in the French noun phrase. The technique used in collecting data on determinants is done by reading technique. For each data found is recorded and classified to be inserted into the data table. The data that has been collected is then analyzed. Data analysis uses a structural approach to view the grammatical system of French noun phrases. The analysis is combined with a semantic reference to see the acceptability of a construction.

The results showed that the elements of noun phrase (nouns and determinants) are obligatory. The determinant types in French noun phrases are (1) l'article (indéfini/défini), (2) l'adjectif (démonstratif, posessif, numeral, indéfini dan qualificatif). The meaning contained in French noun phrase depends on the result of its construction.
\end{abstract}

Keywords: French, noun phrases, determinants, constructions

\section{PENDAHULUAN}

Setiap bahasa memiliki ciri khas masing-masing. Kekhususan tersebut tampak pada kaidah bahasa masing-masing bahasa. Demikian pula halnya dengan bahasa Prancis, yang merupakan salah satu bahasa asing yang dipelajari pada tingkat SMA/SMK/MA dan di perguruan tinggi di Indonesia. Kekhusussan yang terdapat 
dalam bahasa Prancis tampak pada perubahan dan penyesuaian pembentukan verba, nomina dan adjektiva pada konteks yang menyertainya. Perubahan pada pembentukan verba terjadi pada sitem konjugasi. Perubahan pada pembentukan nomina dan ajektiva pada sistem deklinasi (Verhaar, 2001: 139-199).

Dalam bahasa Prancis, nomina selalu disertai dengan determinan sebagai qlassificateur. Determinan merupakan penanda jenis dan jumlah yang digunakan sebagai penyerta nomina bahasa Prancis. Dengan demikian deter- minan adalah satuan gramatika yang menyertai setiap nomina (frasa nominal, yang selanjutnya ditulis FN ) bahasa Prancis yang berfungsi untuk menunjuk dan membatasi nomina yang disertainya. Pembahasan nomina dalam bahasa Prancis tidak dalam bentuk kata (nomina) berdiri sendiri, namun dalam bentuk frasa. Determinan dalam bahasa Prancis, akan selalu menyesuaikan dengan nomina yang didampinginya. Salah satu bentuk perubahan nomina bahasa Prancis dapat dilihat pada kasus nominatif berikut.

$\begin{array}{llll}\text { Un } & \text { livre } & ->\text { Des } & \text { livres } \\ \text { Art. Indéf } & \text { N. Mask. Tngl. } & ->\text { Art. Indéf } & \text { N. Mask. Jmk } \\ \text { (sebuah) } & \text { buku } & ->\varnothing & \text { buku-buku }\end{array}$

Kata sandang un 'sebuah' yang berfungsi sebagai determinan, baik dalam bahasa Prancis maupun dalam bahasa Indonesia menunjukkan jumlah nominanya, namun dalam bahasa Prancis determinan un juga menunjukkan bahwa nomina yang menyertainya (livre) berjenis maskulin. Perubahan tampak pada penggunaan kata sandang des pada 'des livres'. Penggunaan

determinan 'des' menunjukkan bahwa nomina yang menyertainya berjumlah jamak. Penanda jamak pada nomina ini tampak dengan penambahan sufiks $\{-\mathrm{s}\}->$ livres.

Bentuk determinan yang mendampingi nomina berjenis feminin tidak sama dengan determinan yang mendampingi nomina berjenis maskulin, seperti yang tampak berikut ini.

$\begin{array}{llll}\text { Un } & \text { voiture } & ->\text { Des } & \text { voitures } \\ \text { Art. Indéf } & \text { N. fem. Tngl } & ->\text { Art. Indéf } & \text { N. fem. Jmk } \\ \text { (sebuah) } & \text { mobil } & ->\varnothing & \text { mobil-mobil }\end{array}$

Kedua contoh di atas merupakan salah satu bentuk determinan yang digunakan untuk menyertai nomina dalam FN bahasa Prancis. Unsur deteminan sebagai pendamping nomina bahasa Prancis bersifat obligatif. Selain itu pembentukan determinan dalam FN sangat bervariasi dan memiliki ciri khas (unik). Dalam bahasa Indonesia perubahan bentuk determinan yang digunakan sebagai pendamping nomina dalam FN tidak serumit dalam pembentukan determinan sebagai pendamping nomina dalam FN bahasa Prancis.

\section{Pengertian Nomina}

Nomina secara sintaktik adalah kategori yang tidak memiliki potensi untuk bergabung dengan partikel 'tidak' dan tidak dapat didahului oleh partikel 'dari' (Kridalaksana, 1994:79). Dalam bahasa Prancis Bescherell 2006: 188) menjelaskan bahwa 'Le nom est un mot qui désigne une personne, un animal ou une chose. Le

nom est noyau du groupe nominal (on dit parfois le chef du groupe). C'est un élément indispensableau groupe nominal. Il n'existe pasde groupe nominal sans nom'. Berdasarkan pendapat di atas dapat dilihat bahwa nomina merupakan suatu kata yang mengacu pada orang, binatang atau sesuatu. Nomina juga merupakan unsur yang mutlak pada Frasa Nomina (FN), tidak ada FN tanpa nomina.

Nomina dalam bahasa Prancis mengenal jenis (maskulin/feminin) dan jumlah (tunggal/jamak).Yves Loiseau (1997:11), Delatour (2003: 108) mengatakan bahwa penanda jenis dan jumlah sangat mendasar peranannya dalam bahasa Prancis karena keduanya menimbulkan kaidah konkordansi yang dapat mempengaruhi bentuk dan makna suatu kata. Genre diartikan sebagai kategori gramatikal yang menunjukkan jenis kelamin nomina (maskulin atau feminin), sedangkan nombre merupakan kategori grama- 
tikal yang menunjukkan bentuk tunggal dan jamak (Dubois dkk, 2002: 666, ).

\section{Jenis Nomina}

Grevisse (2002:452-453) menjelaskan bawa nomina dalam bahasa Prancis dibagi atas (a) les noms concrets et les noms abstraits (nomina kongkret dan nomina abstrak), (b) les noms animés et les noms in animés (nomina bernyawa dan nomina tidak bernyawa), (c) les noms collectifs et les noms individuels (nomina kolektif dan nomina yang memiliki makna satu). Les noms concrets et les noms abstraits (nomina kongkret dan nomina abstrak) menunjukkan bahwa les noms concrets mengacu pada benda atau manusia, misal: maison 'rumah', voiture 'mobil' homme 'laki-laki'. Les noms abstraits mengacu pada konsep atau pengertian, misal kata bonheur 'kebahagiaan', dan patience 'kesabaran'.

Les noms animés (nomina bernyawa) mengacu pada manusia atau binatang, seperti kata femme 'wanita' chat 'kucing'. Les noms in animés (nomina tidak bernyawa) misal avion 'pesawat dan porte 'pintu'. Les noms collectifs ( nomina kolektif) mengacu pada sekelompok manusia, benda atau tanggapan/ide, misal kata tas 'kumpulan', dan troupeau 'kawanan'. Les noms individuels (nomina yang memiliki makna satu) mengacu ada nomina yang memiliki makna satu, misal un sac 'sebuah tas' dan un homme 'seorang pria'.

\section{Frasa Nomina}

Unsur pembentuk frasa nomina adalah nomina sebagai unsur inti dan determinan yang bersifat membatasi makna.Dengan demikian, frasa nomina terdiri atas nomina sebagai inti dan modifikator yang berkategori berbeda dengan intinya. Menurut Bescherell (2006:96) 'le syntagme nominal est constitué des éléments. Le premier élément est un determinant, le second est un nom' (frasa nomina dibentuk oleh unsurunsur. Unsur pertama adalah determinan, unsur kedua adalah nomina. Berdasarkan posisinya, determinan pada frasa nomina dibagi atas 3 , yaitu: (1) predeterminan, (2) central determinan, dan (3) postdeterminan.

\section{Determinan dalam Bahasa Prancis}

Determinan adalah satuan gramatikal yang menyertai setiap nomina (Frasa Nomina/ FN) bahasa Prancis yang berfungsi untuk menunjuk dan membatasi nomina yang disertainya. Determinan dalam bahasa Prancis merupakan sebuah morfem terikat yang tidak dapat berdiri sendiri tanpa adanya sebuah nomina. Pada konstruksi FN, terdapat berbagai jenis determinan yang penggunaannya memiliki ciri khusus dan masing-masing memiliki makna yang berbeda (Joelle Gardes-Tamine.1998, Delatour Y dkk. 2004 dan Lehnamme et Martin Berthle. 2000).

Dalam bahasa Prancis kata sandang (les articles) berfungsi sebagai determinan. Bentuk kata sandang dalam bahasa Prancis yaitu: (a) kata sandang tak tentu (l'article indéfini : un, une, des (b) kata sandang tertentu (l'article défini: le, la, les) (c) ) kata sandang untuk benda yang tidak dapat dihitung (l'article partitif du, de la, des ) (Bescherelle,1990, Berard, E.2007).

L'article défini digunakan sebagai pendamping nomina yang merujuk pada seseorang atau benda yang bersifat unik) atau telah diketahui sebelumnya, yang dikenal secara umum. Dengan kata lain dapat dikatakan bahwa l'article défini digunakan untuk menyertai nomina yang sudah dibicarakan sebelumnya atau untuk nomina yang telah umum diketahui orang serta untuk nomina yang menunjuk pada hal yang khusus (hanya ada satu). Dengan demikian dapat dikatakan bahwa jika seseorang atau sesuatu yang dibicarakan sudah jelas siapa dan apa. Sebaliknya l'article indéfini digunakan sebagai pendamping nomina yang merujuk pada seseorang atau benda yang belum dikethui sebelumnya (Delatour, J. 2002 : 37-39). Dengan kata lain l'article ini digunakan untuk sesuatu atau seseorang yang belum diketahui. Pembentukan l'article ini sesuai dengan jenis dan jumlah nomina pada frasa nominal yang disertainya. L'article partitif digunakan untuk menyertai bagian dari suatu nomina yang tidak dapat dihitung. Bentuk l'article ini merupakan gabungan dari preposisi de + l'article défini (le, la l'). L'article yang digunakan disesuaikan dengan jenis nomina yang menyertainya

L'article partitif digunakan untuk menyertai bagian dari suatu nomina yang tidak 
dapat dihitung. Bentuk l'article ini merupakan gabungan dari preposisi de + l'article défini (le, la l'). L'article yang digunakan disesuaikan dengan jenis nomina yang menyertainya.

Bentuk lain yang digunakan sebagai determinan (penyerta frasa nomina) dalam bahasa Prancis adalah kata penentu/kata tunjuk (l'adjectif demonstratif), baik yang menunjuk pada seseorang ataupun sesuatu.

$L$ 'adjectif demonstratif digunakan untuk menunjuk nomina yang sudah jelas dan biasanya dekat pembicara. Bentuk l'adjectif demonstratif menyesuaikan dengan jenis dan jumlah nomina yang didampinginya. Bentuk ce untuk nomina maskulin tunggal (singgulier), cette untuk nimina feminin tunggal (singgulier), dan ces untuk nomina maskulin/feminin jamak (pluriel) (Delatour, J. 2002 : 48). Dengan demikian dapat dikatakan bahwa l'adjectif demonstratif digunakan untuk menunjuk seseorang atau sesuatu (nomina, baik berupa sebuah objek ataupun ide).

L'adjectif possessif (kepemilikan) sebagai determinan digunakan untuk mendampingi nomina yang berfungsi untuk menyatakan milik. Pembentukan kepemilikan (l'adjectifpossessif) disesuaikan dengan pronominanya. L'adjectif possessif digunakan untuk menjelaskan kepemilikan seseorang terhadap benda (nomina). Oleh karena itu, l'adjectif possessif ini juga menyesuaikan dengan jenis dan jumlah benda (nomina) yang dimiliki oleh seseorang tersebut. Dengan demikian dapat disimpulkan bahwa l'adjectif possessif digunakan untuk mendampingi nomina dan bermakna untuk menyatakan milik. Berdasarkan uraian dalam kajian teori di atas dapat dikatakan bahwa determinan yang menyertai nomina bahasa Prancis sangat bervariasi, sangat menarik untuk dianalisis sebagai bagian dari kajian linguistik.

Subjek penelitian ini adalah klausa bahasa Prancis yang terdapat pada buku ajar "ECHO". Dengan demikian yang menjadi sumber data penelitian adalah buku ajar "ECHO". Buku ajar "ECHO" adalah buku ajar yang digunakan dalam matakuliah keterampilan berbahasa dan Gramatikal bahasa Prancis di Jurusan Pendidikan Bahasa Prancis Fakultas Bahasa dan Seni, Universitas Negeri Yogyakarta.

\section{METODE}

Data diperoleh dengan teknik observasi, (Spreadley, 1980) dengan tidak meninggalkan metode deskriptif (Sudaryanto, 1993).Teknik yang digunakan dalam pengumpulan data tentang determinan dalam bahasa Prancis dilakukan dengan teknik baca. Teknik lanjutan yang digunakan berupa teknik simak dan teknik catat. Untuk setiap data yang ditemukan dicatat dan diklasifikasi untuk dimasukkan ke tabel data.

Data yang telah dikumpulkan selanjutnya dianalisis. Analisis data menggunakan pendekatan struktural untuk melihat sistem gramatikal frasa nomina bahasa Prancis. Analisis tersebut dipadukan dengan acuan semantik untuk melihat keberterimaan sebuah konstruksi.

\section{HASIL DAN PEMBAHASAN}

\section{A. Pembahasan Hasil Penelitian}

1. Konstruksi Frasa Nomina (FN) dengan les articles adalah sebagai berikut.

a. Les Articles : Défini, Indéfini

Konstruksi Frasa Nomina (FN) dengan determinan l'article défini dan indéfini dapat dilihat pada data-data berikut.

\begin{tabular}{|c|c|c|}
\hline (1) & un & $\underline{\operatorname{taxi}}(\mathrm{E} \mathrm{I} / \mathrm{H} .12)$ \\
\hline & $\begin{array}{l}\text { Art. Indéf } \\
\text { (sebuah) } \\
\text { (taksi) }\end{array}$ & $\begin{array}{l}\text { N-mskln-tngl } \\
\text { taxi }\end{array}$ \\
\hline (2) & un & musée (E I/H.12) \\
\hline & $\begin{array}{l}\text { Art. Indéf } \\
\text { (sebuah) } \\
\text { (sebuah museum) }\end{array}$ & $\begin{array}{l}\text { N-mskln- tngl. } \\
\text { museum }\end{array}$ \\
\hline (3) & une & adresse (E I/H.12) \\
\hline & $\begin{array}{l}\text { Art. Indéf } \\
\text { (sebuah) } \\
\text { (sebuah alamat) }\end{array}$ & $\begin{array}{l}\mathrm{N} \text {-fem- tngl. } \\
\text { alamat }\end{array}$ \\
\hline (4) & une & voiture (E I/H. 15) \\
\hline & $\begin{array}{l}\text { Art. Indéf } \\
\text { (sebuah) } \\
\text { (sebuah mobil) }\end{array}$ & $\begin{array}{l}\text { N-fem- tngl. } \\
\text { mobil }\end{array}$ \\
\hline
\end{tabular}

Frasa nomina un taxi (sebuah taxi) di atas terdiri atas l'article indéfini un sebagai determinan dan nomina taxi sebagai unsur inti. Nomina taxi berjender maskulin tunggal. Demikian pula pada frasa nomina un musée (sebuah museum) terdiri atas l'article indéfini un sebagai determinan dan nomina musée sebagai unsur inti. Nomina musée berjender maskulin 
tunggal. Penggunaan l'article indéfini un pada kedua data di atas disesuaikan dengan jender nomina yang mengikutinya, Sebaliknya pada frasa nomina une adresse (sebuah alamat) dan une voiture (sebuah mobil), l'article indéfini une digunakan sebagai determinan. l'article indéfini 'une' digunakan untuk pedamping nomina berjender feminin yang secara gramatikal bermakna tunggal.

Jika nomina sebagai unsur inti pada frasa nomina berjumlah jamak, maka l'article indéfini yang digunakan sebagai determinan adalah des. L'article indéfini 'des' ini mendampingi nomina berjender maskulin dan feminin. Penggunaan l'article indéfini 'des' pada FN dapat dilihat pada data berikut.

$\begin{array}{ll}\text { (5) des } & \text { montres (E I/15) } \\ \text { Art. Indéf } & \text { N-fem-jmk. } \\ \varnothing & \text { Jam-jam } \\ \text { (jam) } & \\ \text { (6) } \text { des } & \text { voitures (E I/15) } \\ \begin{array}{l}\text { Art. Indéf } \\ \varnothing\end{array} & \begin{array}{l}\text { N-fem-jmk. } \\ \text { mobil-mobil }\end{array} \\ \text { (mobil) } & \\ \text { (7) } \begin{array}{l}\text { des } \\ \text { Art. Indéf }\end{array} & \text { avions (E I/15) } \\ \varnothing & \text { pesawat-pesawat } \\ \text { (pesawat) } & \\ \text { (8) des } & \text { parfums (E I/H. 15) } \\ \text { Art. Indéf } & \text { N-mskln-jmk. } \\ \varnothing & \text { parfum-parfum } \\ \text { (parfum) } & \end{array}$

Nomina montres (jam-jam) dan voitures (mobil-mobil) pada data di atas berjender feminin. Nomina avions (pesawat-pesawat) dan parfums (parfum-parfum) berjender maskulin. Secara gramatikal keempat nomina tersebut bermakna jamak. Determinan yang digunakan pada keempat frasa nomina tersebut adalah l'article indéfini 'des'. Bentuk 'des' digunakan untuk nomina (maskulin dan feminin) berjender jamak. Dengan demikian, konstruksi frasa nomina jamak adalah des $+N$.

\section{b. Les Articles Partitifs.}

Konstruksi FN dengan l'article partitif tampak pada contoh-contoh data berikut ini.
(9)

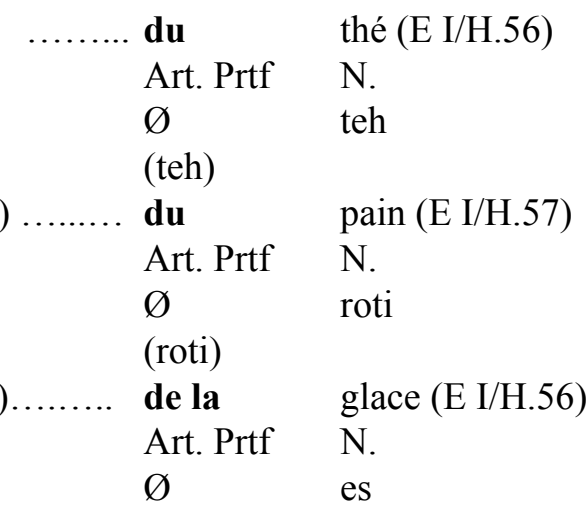

(es)

(12)

de la

bière (E I/H.56)

Art. Prtf N.

$\varnothing \quad$ bir

(bir)

Nomina thé (teh), pain (roti) glace (es) dan bière (bir) merupakan le nom incomptable (nomina yang tidak dapat dihitung dalam satuan konkrit). Berdasarkan kaidah nomina dalam bahasa Prancis, nomina thé (teh), dan pain (roti) berjender maskulin. Nomina glace (es) dan bière (bir) berjender feminin. L'article partitif $d u$ sebagai determinan digunakan sebagai pendamping nomina berjenis maskulin dan l'article partitif de la sebagai determinan digunakan sebagai pendamping nomina berjenis feminin. L'article partitif $d u$ dan de la digunakan untuk 'le nom incomptable' yang diawali dengan konsonan. Jika 'le nom incomptable' diawali dengan vokal, l'article partitif yang mengikutinya adalah de l', seperti pada data berikut.

$\begin{array}{ll}\text { (13) ......... de l' } & \text { eau (E I/H.56) } \\ \text { Art. Prtf } & \text { N. } \\ \varnothing & \text { air } \\ \text { (air) } & \end{array}$

Jika le nom incomptable berjumlah jamak, l'article partitif yang mengikutinya adalah des seperti pada data berikut.

$\begin{array}{rll}\text { (14) ......... } & \text { des } & \text { cereals (E I/H.61) } \\ & \text { Art. Prtf } & \text { N. } \\ & \varnothing & \text { sereal } \\ & \text { (sereal) } & \\ & \\ (15) \ldots \ldots \ldots . & \text { des } & \text { confitures (E I/H.61) } \\ & \text { Art. Prtf } & \text { N. } \\ & \varnothing & \text { selai } \\ & \text { (selai) } & \end{array}$


Dalam bentuk negatif, l'article partitif $d u$, de la dan des berubah menjadi de, seperti tampak pada data berikut.

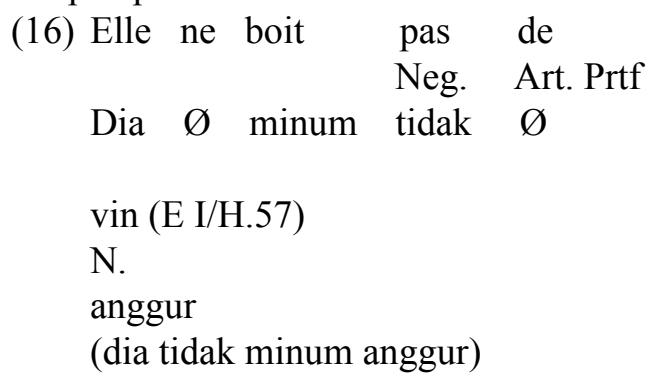

$\begin{array}{lll}\text { (17) Elle ne mange pas de } \\ & & \text { Neg. Art. Prtf }\end{array}$

Dia $\varnothing$ makan tidak $\varnothing$

pain

$\mathrm{N}$.

roti

(dia tidak makan roti)

\section{c. Les Articles Contractés}

Les articles contracté berasal dari preposisi à atau de yang diikuti oleh l'article défini: àlde + le/la/les. FN dengan determinan l'article contracté tampak pada data berikut ini.
(18) ... des cocombre au aourt (E I/H.59)
Art. N. Art.Ctr N
$\varnothing$ mentimun $\varnothing \quad$ yoghurt (yoghurt mentimun)
(19) .... les tartes aux ommes (E I/H.59)
Art. N Art.Ctr N
$\varnothing$ pai $\varnothing \quad$ apel
(pai pel)
(20) ... rentre du travail (E I/H.61)
$\mathrm{V}$ Art.Ctr N
Kembali dari pekerjaan
(pulang kerja)
(21) les habitudes des Français (E I/H.61)
Art. N. Art.Ctr N
$\varnothing$ masyarakat $\varnothing \quad$ Prancis
(masyarakat Prancis)

Dari data-data di atas dapat dilihat bahwa l'article contracté yang diikuti oleh nomina dalam bahasa Prancis merupakan gabungan dari preposisi à atau de dan l'article défini. Pada data “.... au yaourt", l'article contracté au berasal dari preposisi $\grave{a}+$ l'article défini le (jika nomina berjenis maskulin dan berjumlah tunggal). Pada data “..... aux pommes", l'article contracté aux berasal dari preposisi $\grave{a}+$ l'article défini les (untuk nomina berjenis maskulin/feminin dan berjumlah jamak).

Pada data ".... du travail", l'article contracté $\boldsymbol{d u}$ berasal dari preposisi $\boldsymbol{d e}+$ l'article défini le (jika nomina berjenis maskulin dan berjumlah tunggal). Pada data “....des Français, l'article contracté des berasal dari preposisi $\boldsymbol{d e}+$ l'article défini les (untuk nomina berjenis maskulin/feminin jamak).

L'article contracté aux pada FN ....les tartes aux pommes (pai apel) dan l'article contracté au pada FN ...... des cocombre au yaourt (yoghurt mentimun) berfungsi untuk menunjukkan komposisi. L'article contracté des pada FN les habitudes des Français (masyarakat Prancis) berfungsi menunjukkan keanggotaan. L'article contracté du pada FN ...... rentre du travail (pulang dari tempat kerja) berfungsi untuk memberi makna 'tempat kerja' pada nomina travail.

\section{Les Adjectifs Démonstratifs}

Bentuk determinan lainnya yang digunakan sebagai pendamping FN dalam Bahasa Prancis adalah les adjectifs démonstratifs, seperti yang tampak pada data-data berikut.

(22) ...... ce stylo (E I/H.57)

Art. Dmnst. N ini ballpoint

(23) ........et appartement (E I/H.71)

Art. Dmnst. N ini apartemen

(apartemen ini)

(24) ...... cette actrice (E I/H.152)

Art. Dmnst. N ini artis

(artis ini)

(25)..... ces courtes scenes (E I/H.141)

Art. Dmnst. Adj. N Ini singkat episode

(episode yang singkat ini)

Pada data data di atas tampak bahwa l'adjectif démonstratif digunakan untuk menunjuk seseorang atau sesuatu. L'adjectif démonstratif 'cet' digunakan sebagai pendamping nomina berjender maskulin yang diawali dengan 
huruf vokal atau huruf ' $h$ ' yang tidak terucap. $L$ 'adjectif démonstratif 'cette' digunakan sebagai pendamping nomina berjender feminin tunggal. L'adjectif démonstratif ces digunakan sebagai pendamping nomina berjender maskulin atau feminin jamak.

\section{Les adjectifs possesifs}

Frasa Nomina (FN) yang pembentukannya menggunakan l'adjectif possesif tampak pada beberapa data berikut ini.

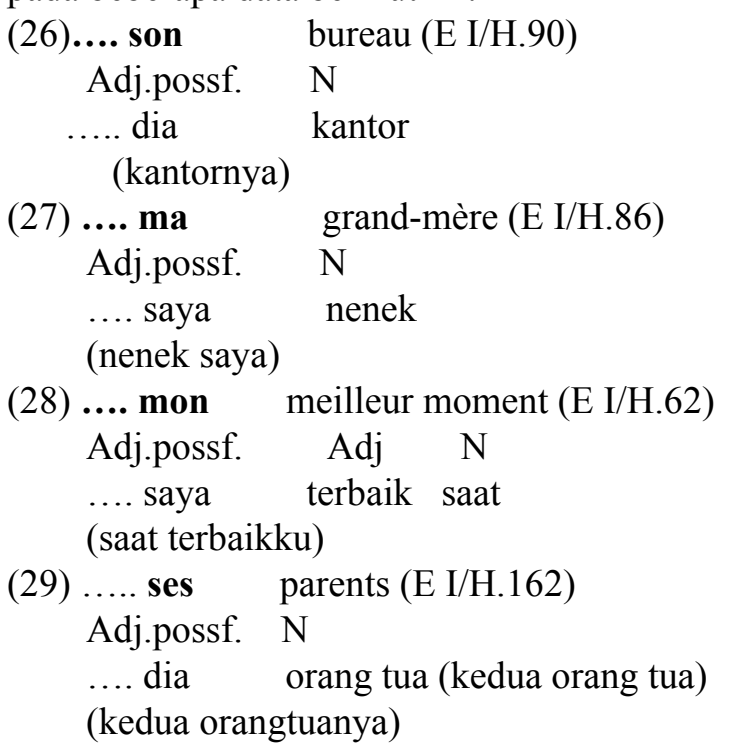

Pada frasa nomina (27) dan (28) di atas tampak bahwa l'adjectif possessif yang digunakan adalah untuk orang pertama tunggal (je) pada data (27) .... ma grand-mère (nenek saya) dan data (28) .... mon meilleur moment (saat terbaikku). Pada kedua data tersebut tampak bahwa perubahan l'adjectif possessif sesuai dengan jenis nomina yang disertai oleh l'adjectif possessif yang menyatakan kepemilikan.

$L^{\prime}$ 'adjectif possessif $\boldsymbol{m a}$ digunakan sebagai pendamping nomina feminin tunggal. Nomina mère berjenis feminin tunggal, oleh karena itu l'adjectif possessif yang digunakan adalah ma (ma grand-mère -> frasa nominal). Nomina moment berjenis maskulin tunggal, oleh karena itu l'adjectif possessif yang digunakan adalah 'mon' (mon meilleur moment -> frasa nominal ). Pada data (26) .... son bureau (kantornya), l'adjectif possessif yang digunakan adalah untuk orang. Ketiga tunggal (i1/elle). Nomina bureau berjenis feminin tunggal, oleh karena itu l'adjectif possessif yang digunakan adalah son (son bureau -> frasa nominal). Pada data (29) ..... ses parents (orang tuanya), nomina parents berjumlah jamak, oleh karena itu l'adjectif possessif yang digunakan adalah ses (mes lunettes-> frasa nominal).

\section{Les Adjectifs Numéraux}

Determinan lainnya, sebagai pendamping FN dalam Bahasa Prancis adalah les adjectifs numéraux, seperti yang tampak pada data-data berikut.

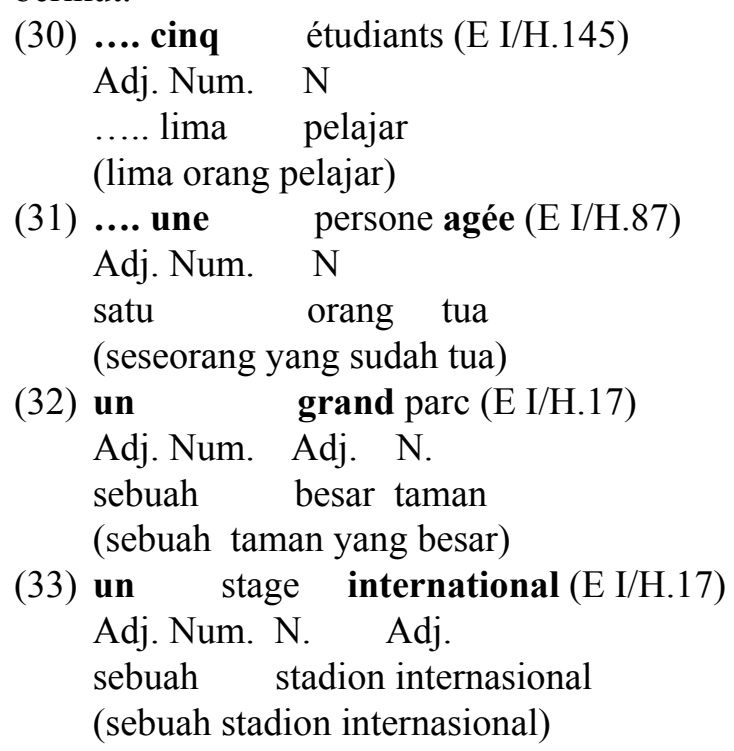

Les adjectifs numéraux cinq, une dan un pada data (30) sampai (33) merupakan determinan nueralia numerik, yang menunjukkan jumlah, dari nomina yang terdapat pada masing-masing data di atas. Pada data (31) une persone agée (seseorang yang sudah tua), selain l'adjectifnumeral un sebagai determinan dari nomina persone, terdapat kata agée (dalam bentuk participe passé). Bentuk participe passé agée digunakan sebagai ajektiva yang memberi penjelasan tentang nomina persone.

Pada data (32) un grand parc (sebuah taman yang besar), perluasan FN terjadi dengan penambahan ajektiva grand. Dalam Bahasa Prancis bentuk ajektiva yang pendek biasanya terletak di depan nomina. Adjektiva grand pada frasa nomina un grand parc adalah l'adjecif qualificatif yang menunjukkan ukuran. Pada data (33) un stage international (stadion internasional) l'adjecif qualificatif 'international' menjelaskan karakteristik dari nomina stage (sebagai inti FN). Berdasarkan teori gramatika 
bahasa Prancis Adjektiva selalu dilektakkan di depan nomina yang dijelaskannya. Dalam bahasa Prancis konkordansi antara adjektiva dan nominanya memiliki beberapa kaidah (Olivier, 1978: 234, Bescherelle, 1990: 164-168). Secara umum (seperti yang telah dibahas pada frasa nominal),jika adjektiva menyertai nomina yang berjenis feminin tunggal ada penambahan sufiks $\{-e\}$ pada adjektivanya, penambahan sufiks $\{-s\}$ jika adjektiva menyertai benda maskulin jamak, dan penambahan sufiks $\{-e s\}$ jika adjektiva menyertai benda feminin jamak. Bentukbentuk tersebut tampak pada data berikut.

(34) Une

belle ville

Adj. Num. Adj. N.

Sebuah indah kota

(sebuah kota yang indah)

(35) Des

grandes maisons

Adj. Num. Adj. N.

$\varnothing \quad$ besar rumah

(rumah-rumah yang besar)

\section{Les Adjectifs Indéfinis}

Penggunaan l'adjectif Indéfini sebagai determinan pada Frasa Nomina tampak pada data data berikut ini.

(36) beaucoup de magazines (E I/H.157)

Adj. Indéf. Prep. N

banyak $\varnothing$ majalah

(banyak majalah)

(37) tous les soirs (E I/H.86)

Adj. Indéf. Art. Déf. N

semua $\varnothing \quad$ sore-sore

(setiap sore)

(38) chaque groupe (E I/H.35)

Adj. Indéf. $\mathrm{N}$

Setiap kelompok

(setiap kelompok)

(39) certaines personnes .... (E I/H.168)

Adj. Indéf. $\mathrm{N}$

tertentu orang-orang

(orang-orang tertentu .....)

(40) .... quelques personnes (E I/H.168)

Adj. Indéf. $\mathrm{N}$

beberapa orang-orang

(beberapa orang)

Bentuk beaucoup de (banyak), tous (semua), chaque (setiap), certaines (tertentu), dan quelques (beberapa) merupakan numeralia non numerik dari kelas kata l'adjectif Indéfini. Namun setiap l'adjectif Indéfini tersebut di atas memiliki kekhasan masing-masing. Les adjectifs Indéfinis beaucoup de (banyak) dan certaines (tertentu) selalu diikuti oleh nomina jamak. Beaucoup de (banyak) dan quelques (beberapa) tidak menyesuaikan dengan jender nomina yang didampinginya. Certaines (tertentu) digunakan sebagai pendamping nomina berjender feminin jamak, certains (tertentu) digunakan sebagai pendamping nomina berjender maskulin jamak, seperti pada data: certains nom ... (E I/H.166). Nomina nom berjender maskulin tunggal.

L'adjectif Indéfini tous (semua) memiliki bentuk sesuai dengan nomina yang didampinginya. Tous untuk nomina berjender maskulin jamak. Tout jika nomina yang mengikutinya berjender maskulin tunggal. Toute jika nomina yang mengikutinya berjender feminin tunggal, dan toutes jika nomina yang mengikutinya berjender feminin jamak. L'adjectif Indéfini tous (semua) pada data (33) tous les soirs (setiap sore), l'adjectif Indéfini tous merupakan predeterminan, terletak di depan l'article défini les, yang merupakan determinan dari nomina soirs. Dari semua l'adjectif Indéfini pada data (32) sampai (36) di atas, hanya l'adjectif Indéfini tous yang bisa menjadi predeterminan. L'adjectif Indéfini tous juga dapat diikuti oleh l'adjectif posessif, seperti pada data: tous mes amis.... (E I/H.168). L'adjectif posessif mes pada data di atas merupakan determinan dari nomina amis. $L$ 'adjectif Indéfini tous merupakan predeterminan pada FN tous mes amis.

L'adjectif Indéfini chaque (setiap) merupakan kelas kata l'adjectif Indéfini yang tidak mengalami perubahan bentuk. L'adjectif Indéfini chaque digunakan sebagai determinan dari nomina tunggal pada FN. Nomina yang merupakan inti pada FN yang determinannya l'adjectif Indéfini chaque berjender feminin dan maskulin

\section{SIMPULAN}

Berdasakan hasil analisis data yang diuraikan pada pembahasan di atas, dapat disimpulkan bahwa unsur dasar pembentuk frasa nomina dalam Bahasa Prancis adalah determinan dan nomina sebagai intinya. Kedua unsur ini bersifat obligatoris. Jenis determinan pada frasa 
nomina Bahasa Prancis adalah (1) l'article (indéfini/défini), (2) l'adjectif(démonstratif, posessif, numeral, indéfini dan qualificatif). Konstruksi frasa nomina Bahasa Prancis disesuaikan dengan makna yang tergandung pada frasa nomin tersebut. Pada konstruksi FN: Numeralia (det) + Nomina, numeralia memiliki makna adverbial kuantitatif. Adjektiva pada konstruksi FN: Det $+\mathrm{N}+$ adjektiva, berhubungan dengan kualitas, karakteristik dan sebagai atribut.

Berdasarkan bentuk-bentuk frasa nominal di atas dapat dikatakan bahwa nomina bahasa Prancis tidak bisa lepas dari déterminantnya. Penentu tersebut untuk melihat jenis dan jumlah nominanya. Selain itu, nomina tunggal yang berubah menjadi jamak juga memiliki tambahan sufiks penanda jamak

\section{DAFTAR PUSTAKA}

Baryadi, I. 2001. Asas-Asas Linguistik Umum. Yogyakarta: Gadjah Mada University Press

Berard, E. 2007. Grammaire du Francais, Atelier FLE. Parir: Didier

Bescherelle. 2006. La Grammaire pour Tous. Paris: HATIER

Binardet, Jacky dan Pécheur, Jacque. 2002. Campus Méthode de Français. Paris: CLE Inetrnationale
Delatour, J. 2003. La Nouvelle Grammaire $d u$ Francais. Paris: Hachette

Dubois, Jean, dkk. 2002. Dictionnaire de Linguistique. Paris: Larousse.

Girardet, Gibbe.C. 2008. Echo. Paris: CLE Inetrnationale

Grevisse, Maurice.2013. Le Bon Usage: Le Grammaire Francaise. Paris: Edition du Boeck Université

Kridalaksana, Harimurti. 2001. Kamus Linguistik. Jakarta : Gramedia Pustaka Utama.

Kridalaksana, Harimurti.2007. Kelas Kata dalam Bahasa Indonesia.Jakarta: Gramedia Pustaka Utama

Loiseau Yves. 1997.Point par Point. Cahier Débutant. Paris: Didier

Spredley. 1980. Participant Observation. WADSWORTH : Gengage Learning

Sudaryanto. 1993. Metode dan Aneka Teknik Analisis Bahasa. Jogjakarta: Duta Wacana University Press

Tamine Joelle Gardes-.2015. Cours de Grammaire Francaise. Paris: Cle International

Verhaar,J.W.M. Alip, B.Fr. Aryanto,A. Ria Lestari, B. Mukarto, F.X. Praptomo 